University of Nebraska - Lincoln

DigitalCommons@University of Nebraska - Lincoln

Faculty Publications: Department of Teaching, Department of Teaching, Learning and Teacher Learning and Teacher Education

Education

2020

Digital Storytelling with English Language Learning Families

Stephanie Wessels

University of Nebraska-Lincoln, swessels2@unl.edu

Guy Trainin

University of Nebraska-Lincoln, gtrainin2@unl.edu

Follow this and additional works at: https://digitalcommons.unl.edu/teachlearnfacpub

Part of the Curriculum and Instruction Commons, and the Teacher Education and Professional Development Commons

Wessels, Stephanie and Trainin, Guy, "Digital Storytelling with English Language Learning Families" (2020). Faculty Publications: Department of Teaching, Learning and Teacher Education. 425.

https://digitalcommons.unl.edu/teachlearnfacpub/425

This Article is brought to you for free and open access by the Department of Teaching, Learning and Teacher Education at DigitalCommons@University of Nebraska - Lincoln. It has been accepted for inclusion in Faculty Publications: Department of Teaching, Learning and Teacher Education by an authorized administrator of DigitalCommons@University of Nebraska - Lincoln. 


\section{Digital Storytelling with English Language Learning Families}

\section{Stephanie Wessels}

University of Nebraska-Lincoln, USA

Guy Trainin

University of Nebraska-Lincoln, USA

\section{ABSTRACT}

In this chapter, we examine the design process and outcomes of a digital storytelling with elementary-aged English Language Learning Families. The program was iterated through a multi-step design process to integrate the use of digital storytelling on mobile devices with family literacy. In this chapter, we explain why adults and children needed worktime separately before they collaborate and that a focus on funds of language, culture and relevance foster willingness to engage with digital literacy. In working with English Language Learning Families, we found the following themes: when it comes to schooling, everything is in English; confidence in learning about technology, literacy and storytelling; and coexistence (spending time together). This chapter examines that the power and availability of mobile technologies, coupled with the traditions of storytelling, can transform language and literacy outcomes.

Citation:

Wessels, S, \& Trainin, G. (2020). Digital storytelling with English language learning families. In G. Onchwari \& J. Keengwe (Eds.), Bridging family-teacher relationships for ELL and immigrant students (pp.27-45). Hershey, PA: Information Science Publishing. 


\section{INTRODUCTION}

English Language Learners (ELLs) in the United States educational system, are part of communities and families who have always faced linguistic, cultural, and power challenges in mainstream schools. These challenges lead to a significant English literacy achievement gap between ELLs and their English monolingual peers. For example, in the state where the study took place, only $56 \%$ of fourth grade and $31 \%$ of eighth-grade students who were identified as ELLs (2017) were considered proficient in writing compared to $70 \%$ and $71 \%$ for all students respectively. The gap, identified by state tests, is of limited utility because it fails to identify the students' funds of knowledge. The funds of knowledge which are the untapped cultural experiences of ELLs families (Moll, Amanti \& Gonzalez, 1992) that students have along with contributions of the home language to the development of literacy.

One form of literacy is digital literacy which is the ability to use, create, and read information using technology. Digital literacy is essential for individuals to be fully participating citizens in the 21 st century culture. It is critical for college and career readiness, yet sporadically addressed in schools since it is rarely assessed. Evidence shows that the gaps in digital literacy are much more significant, as much as twice, than those identified in standardized tests (Leu, Kinzer, Coiro, Castek \& Henry, 2013). This finding is worrying since digital literacy has the potential to provide new innovative solutions to reduce the literacy gap. While the potential for positive impact of digital technology on literacy learning has been studied (e.g. Deng \& Trainin, 2015), the research from the New Literacies Research Labs shows that achievement gaps in digital literacy, reading \& writing in digital environments, has a large effect size difference even after accounting for the gaps in traditional literacy (Leu et al., 2013). As a result, we cannot wait on students to meet traditional literacy demands before addressing digital literacy; instead, we 
must work concurrently in both traditional and digital literacies to make sure that students become career and college ready.

In this chapter, we discuss the finding from two digital storytelling iterations with ELL families as a way of meeting those challenges. In the Digital Storytelling with ELLs families program, we studied how using mobile devices to enhance family literacy led to increase literacy engagement between parent and child and digital literacy. The study took place over two years in two elementary schools as a voluntary after-school program. Both elementary schools had a large ELL population and were located in the same school district. The family literacy program was co-created by state university professors, graduate students, district personal, and participating families. Digital storytelling was the medium to focus attention on engagement, language, and technology proficiencies. The curriculum was based on evidence from prior research and included dialogic reading strategies (Lonigan \& Whitehurst, 1998), storytelling features (Thomas \& Collier, 2012), and multimodal media (Lambert, 2006). The content and skills workshops were sequential and collaborative, with the focus of subsequent sessions enhancing previous skills.

\section{FAMILY LITERACY}

Research has shown that families' literacy practices, including oral interactions and joint storybook reading, have a positive impact on children's literacy achievement in school (Trainin, Wessels, Nelson \& Vadasy, 2016; Bus, van Ijzendorn, \& Pellegrini, 1995). However, as Dickinson and Tabors (2002) observed, some adults may lack confidence reading to their children due to lack of prior experience with shared book reading, limited literacy skills, or lack of English proficiency. This reluctance can lead to lesser literacy and language experiences for children in their home environment. In families whose first language is not English, parents often 
provide literacy experiences that do not fully align with school expectations and thus can lead to diminished school outcomes, which widen the achievement gap (Dickinson \& Tabors, 2002; Strucker, Snow \& Alexander, 2004). Research also shows that both families and schools are often reluctant to promote home literacy when it is in a language different than English since they perceive biliteracy as an obstacle instead of a strength (Shin \& Krashen, 1996). Even though research has consistently found that more enriching language experiences in the home language lead to positive outcomes in both the home language and English (Tse, 1998).

Parents of ELLs can use their native language and culture to support their children's literacy development. By providing young children with a firm foundation in their native language, parents of ELLs give them a basis for learning to read and write in both their native language and English. Research has repeatedly shown that language proficiency in a child's first language leads to improved normative literacy (reading and writing) skills in school. Several studies have demonstrated a link between native language knowledge and foundational early English literacy skills (Goodrich, Lonigan, \& Farver, 2013; Proctor, August, Carlo, \& Snow, 2006; Rolla, 2002; Scheele, Leseman, \& Mayo, 2009). By providing young children with a firm foundation in their native language, parents give them a basis for learning to read and learning other languages, including English (Goldenberg, 2008). Thus, more enriching language experiences are possible even when parents use their native language to communicate, but they need help in helping students connect these skills and capacities to school-based expectations.

\section{Storytelling}

Oral storytelling is a common way to communicate cultural practices, care and support children's cognitive and linguistic growth (Thomas \& Collier, 2012). Storytelling is a socialization tool through which ideas, perspectives, and cultural norms are passed down through 
family members (Fiese, 2006). Craig and his colleagues (2001) showed that different cultures use storytelling for different purposes focusing on relationships and kinship more than schooloriented literacy and language. Such storytelling can elicit lively conversations, develop verbal language skills, and provide opportunities to express personal ideas without requiring the English language proficiently.

In this Digital Storytelling with ELL Families program, we bridged the traditional culturally accepted literacy practices (i.e., oral storytelling), and school expected literacy (normative reading and writing) with the affordances of digital storytelling. Digital storytelling integrates oral storytelling with multimodal presentation afforded by technology. Composing a digital story requires authors to reflect on prior knowledge and experiences (Barrett, 2005), to organize information, write, and utilize technology. Researchers who have involved by parents and children in writing activities report increased parental involvement, improved child literacy development and enthusiasm for reading and writing, and increased home-school communication (Albee \& Drew, 2001). Thus, digital storytelling can become a medium in which parents can weave linguistic and cultural connections for their children in both languages using visuals, audio, print, and voice. It has been defined as "the practice of combining narrative with digital content, including images, sound, and video, to create a short movie, typically with a strong emotional component." (Educause Learning Initiative, 2007, p. 1) Parents can become bilingual literacy models for their children because it builds on their funds of knowledge and highlights capacity and the importance of heritage language and culture.

\section{Funds of Knowledge}

Parents provide a wealth of family traditions, knowledge, and experiences for their children. Kyle, McIntyre, Miller and Moore (2005) studied how teachers visited children's 
homes in order to become familiar with and then to build on and support the children's "funds of knowledge" the untapped cultural experiences of families (Moje, Ciechanowski, Kramer, Ellis, Carrillo, and Collazo, 2004; Moll, Amanti and Gonzalez, 1992). Compton-Lilly and her colleagues (2012) concluded that it is crucial for family literacy practitioners, schools, and educators to be aware of the funds of knowledge brought into the school by children and families. The researchers argue that it is critical that school and family literacy practitioners build on these rich diverse literacy practices brought into the classroom.

\section{Technology: Access and Impact}

Mobile technology in the US is ubiquitous. The Pew Internet and Family Life project shows that over $99 \%$ of adults own a cell phone and that over $91 \%$ own a smart device, and $58 \%$ own a tablet (Pew, 2013). For Latinx adults, the rate of smart device use is higher than the US average, and tablet use is equal to other ethnicities (Pew, 2013). These mobile devices present a new opportunity to share educational resources with families and teachers in ways that were not possible just a few years ago. We believe that parents can use commonly available mobile technology to engage with their children more effectively.

Research to support the efficacy of using technology to increase learning is growing, for example, Berkowitz and his colleagues (2015) have recently shown that shared math storytime on iPads has led to increased achievement and motivation in math. Edwards (2006) had explored adult's learning experiences with computers within family literacy programs, and Lewis (2009, 2013) has explored families' technological literacies in the home. There are also a few studies investigating Latinx families' storytelling development in relation to school achievement (e.g. Malo \& Bullard, 2000; Schecter \& Bayley, 2002; Torres, 1997), however, currently, there is very little published research examining the impact of using digital resources with ELL Families. We 
know that technology, now ubiquitous, can enhance the language and literacy outcomes for ELLs in significant ways.

\section{THE DIGITAL STORYTELLING PROGRAM}

\section{Setting and Participants}

CornHaven (pseudonym) is a midwestern city of about 290,000 inhabitants. CornHaven is designated as a refugee-friendly city that has brought any new cultures, languages and religions into the area. Latinx from various countries are the largest immigrant group in the city; however, it is also home for Bosnian, Vietnamese, Afghani, Yazidi, Russian, Kurdish, Sudanese, Ukrainian, Chinese and other immigrant groups.

The voluntary-after school digital storytelling program took place in two elementary schools, Morningside and Hamilton, located in CornHaven Public School District. Morningside Elementary was a Title-1 urban school with $71 \%$ of students on free or reduced lunch. Minority enrollment was $45 \%$ of the student body, with Latinx being the largest group. Four Latinx families, four mothers \& eight children were the program's participants at Morningside. Since the Digital Storytelling program participants were all Latinx, we conducted the program in Spanish and English to ensure full access to the content material of the program.

Hamilton Elementary was also a Title-1 urban school with $91 \%$ of students on free or reduced lunch. Minority enrollment was $68 \%$ of the student body, with the majority being Latinx. We had eight participating families (7 mothers, one father, and 17 children) in the program. Spanish ( 2 mother participants and 9 children), Chinese (3 mother participant and 3 children), Sudanese (1 mother participant and 3 children), and Vietnamese (1 father participant and 2 children) were the languages that were represented in the Hamilton program, so the content 
was delivered in English with native language support through bilingual liaisons from the school district.

Participating children ages in both of the programs were from 3-10 years old. Although the target age group was Kindergarten- $1^{\text {st }}$ grade, we encouraged families to bring all their children to the sessions which allowed inclusivity for the families. We recognized the roles of all family members and supported child care needs of the families to be able to participate in the projects.

\section{The Digital Storytelling Program Procedures and Curriculum}

The Digital Storytelling with ELL Families programs consisted of 8 weekly group sessions. Each session lasted about 90 minutes after the regular school day. The literacy sessions design focused on ways families can use mobile devices to engage as storytellers in their native language or English.

The families created their digital stories on the Little Story Creator App chosen because it was a free app available on both the Android and Apple operating systems. Digital storytelling skills and objectives developed for this program were based on research in media knowledge, reading literacy, dialogic reading strategies, storytelling characteristics (Craig et al., 2001; Lonigan \& Whitehurst, 1998), including (a) labeling (provides a label for objects, person, place; (b) verbal expression (comments on the story being developed), and (c) prior knowledge (questions or comments to encourage recall of previous experience or knowledge related to the story). Families learned the formal aspects of story structure, using visual literacy images, and other skills to tell a story through the use of technology and connect it to their background knowledge and experiences (funds of knowledge). 
In addition to media and literacy knowledge, we used Lambert's seven elements of effective digital stories (2006): 1) Point of view: told from the author's viewpoint; 2) Dramatic Question: attention grabber; 3) Emotional Content: storyline that stirs an emotional connection; 4) Economy: short, time-limited story; 5) Pacing: maintaining a rhythm; 6) The Gift of Voice: participants using their voice; and 7) Soundtrack: the use of music to produce an emotional connection. As the parents and children got better at navigating the storytelling apps, they started to incorporate some of Lambert's elements into their digital stories.

We opted to use a design approach that allowed the curriculum to be flexible and fluid, depending on the needs and interests of the participants. The program was conducted in Spanish and English at Morningside Elementary and English, with native language support, at Hamilton Elementary to guarantee the families and university instructors could participate. Participants were encouraged to use whichever language with which they were most comfortable in when creating their stories. The ability to code-switch, alternating between two languages, allowed participants to negotiate their linguistic repertoires using whichever language they felt was appropriate for different tasks (Garcia \& Kleifgen, 2010). Even though the two programs were conducted in different languages, the content, objectives, and delivery were similar. The sequence of the sessions was: Session \#1) Discuss cultural values \& the concepts of storytelling, and technology; Session \# 2) Identification of the parts of the story \& working with the Little Story Creator App; Session \# 3) Developing and creating a continuous storyline within the context of the digital artifacts; Session \# 4) Active Listening and contributing to each other's stories; Sessions \#'s 5-7) Feedback and finalizing stories; and Session \# 8) Celebration and sharing stories. 
The Digital Storytelling program was first implemented at Morningside Elementary with the outcome of children and parents co-creating their stories. However, during the first session it quickly became apparent that children were "taking over," and the parents were getting progressively frustrated because they were not allowed to practice on the devices. Once the dynamic became apparent, we redesigned the time and separated the children and the parents for initial work allowing parents to gain confidence using the technology. Each group, children and parent, learned the same storytelling and technology skills; however, they were able to work on individual stories at their own pace and topic.

Parents were encouraged to use their mobile devices (smartphone, tablet, or iPad) so they can continue to use it after the project was over. Most families had their own mobile devices and preferred using them; in some cases, we provided iPads loaned to the families throughout the digital storytelling sessions.

\section{RESEARCH METHODS FOR STUDYING THE PROGRAM}

We used a design study approach to study the effects of the program. Design studies are iterative, process-focused, interventionist, collaborative, and based on translation science (Cobb, Confrey, diSessa, Lehrer, \& Schauble, 2003). A key feature is the iterative nature of the design process with the results of each iteration and the new context influencing the next iteration. Shavelson and his colleagues (2003) described them as "they involve tightly linked designanalysis-redesign cycles that move toward both learning and activity or artifact improvement." (p. 26)

In this design study, we relied on qualitative data collection and analysis were conducted during the program to help guide the construction of the curriculum. The guiding question was to study how using mobile devices to enhance increase family literacy engagement and technology 
literacy understanding. Triangulation was assured through multiple sources of data: family technology surveys, interviews of the parents, and field notes that provided contextual information (Agar, 1996).

\section{The Family Technology Survey}

A Family Technology Survey was given at the beginning of the project. The survey asked parents for information about the ages of their children, languages spoken in the home, and technology usage at home (how it is used, accessibility, type of device). This served as an assessment tool to uncover the families' technology literacy knowledge. In particular, it provided information to iterate the design based on results and what the families were interested in learning. The survey included a combination of open-ended questions, which allowed parents to share as much information as they desired to share and rating scale questions. Parents' usage of technology was measured through this survey using a 6-point scale (e.g., I can't and don't want to, I don't have or don't use) (see Appendix 1 for the survey).

\section{Parent Interviews}

A general interview guide approach (Patton, 2002) was used to obtain an insider perspective of participants' beliefs and values. At both program sites, we conducted semistructured interviews the parents at the end of the program. At the Morningside Elementary, the interviews were conducted in Spanish, translated, and transcribed by the bilingual graduate assistant working on the project. At the Hamilton project site, the interviews were conducted in English with clarification questions in their native language. The bilingual liaisons for the district provided immediate translations during the interviews. Each interview was 15-20 minutes in length. The following are the interview questions asked to parents at the end of the program:

1) What did you learn in this project? 
2) What did you like about the technology?

3) Do you feel more comfortable now with this technology abilities that you learned about throughout the project?

4) What did you learn about taking and incorporating photos into a story?

5) What did you learn in the project that you could share with your children?

6) What did you like most about the project, about the session of classes?

7) Do you think you will continue to create stories after the project?

8) If there was something you wanted us to tell the school district, what would be?

9) How to you use language in your home environment?

\section{Field Notes}

The last data source was the researcher's field notes, reflections, observations. After each session, observational notes were made about comments and situations that the parents and children discussed during each session. This process helped the researchers to recall important conversations and issues that happened during interactions with the participants. Field notes included comments specific to individual experiences, suggestions from participants, and session's successes and challenges. The field notes were often design oriented and contained notes about how to extend the learning during the next session or what content we might add to fill in knowledge gaps that were identified during the session.

\section{Data Analysis}

Interview transcripts, field notes, and family surveys were analyzed using open coding technique (Creswell, 2007; Merriam, 2009) and following Tesch's (1990) systematic process of analyzing textual data. Texts were coded into emergent categories that allowed for the identification of themes and patterns in the data. The first step was open coding by taking notes 
to identify patterns and categories. This helped in making sense of the data and establish connections. Next, we used color coding techniques to develop a shortlist of tentative codes. After this step, we reduced and combined categories into three themes. The use of multiple data sources ensured the triangulation of findings helped build trustworthiness (Patton, 2002).

Construct validity (Yin, 1994) was addressed in this study through (a) using multiple sources of data, (b) using different researchers to analyze the data, and (c) establishing a chain of evidence.

\section{FINDINGS AND DISCUSSION}

In the study, the guiding question was to understand how using mobile devices can increase family literacy engagement and technology literacy understanding. After analyzing the data, three themes emerged: when it comes to schooling, everything is in English; confidence in learning about technology, literacy and storytelling; and coexistence (spending time together).

\section{When it comes to schooling, everything is in English}

When it comes to schooling, everything is in English was a theme that emerged from the data suggesting that although many of the family participants were multilingual, they had a difficult time getting access to their native language when it came to information. One parent commented, "The school has a lot of [of emails] that we have to read, [I say] "Come here niece! Read it to me what does it say?" The parents discussed that many times that they struggled to understand or get information from the school because they did not have access to the information in their native language. They felt that they were not involved in the educational concerns of their children.

Some of the parent participants lacked the English proficiency to provide their children with language experiences that align with school expectations because their children were being schooled in an environment dominated by English print. Not being able to access educational 
print left parents feeling that they were unable to participate in their children's education. The underlining message that schools were sending to parents was a neo-deficit ideology that assumes that "parents who are not from the dominant culture are often viewed as lacking the necessary skills and knowledge to help their children succeed in school" (Baquedano-Lopez, Alexander, \& Hernandez, 2013). Schools need to believe that ELL families are assets and how to view the native language is a resource and a strength rather than a barrier. For ELL families, to become active participants in the life of schools, they must be welcomed, valued, and connected to each other and to what their children are learning.

Several of the parents were trying to match the language of delivery in the schools while putting their native language second. "We speak Arabic at home, everyone has to speak it. I tell them Arabic is good. We are trying to teach them to read and write in Arabic. But I need to push them to learn English then we can speak Arabic" commented one of the mothers in the program. She felt that participation in the program was a way to provide opportunities for her children to continue in their learning of English. This comment was not unusual and is something observed in research with ELL families, sacrificing the native language for English as a tool of social mobility and assimilation (e.g. Lopez, 1996). However, research has shown the benefits of having a strong native language. Native language proficiency is a strong predictor of overall language development, and the research has shown that experiences in the native language will transfer to English, strengthen cognitive flexibility, and strengthen identity and thus provide multiple benefits that contribute to a foundation for literacy development (Conner, 2010; Goldenberg, 2008) and overall academic success (Cummins, 1986, Slavin \& Cheung, 2002; S. Lee, 2002). But many times, that is not the message that parents are receiving from schools. Studies have shown that incorporating cultural relevant methods to students not only affirms and 
welcomes students' cultural identities in the classroom but also leads to more successful learning (Johnson \& Fargo, 2014). Students transfer knowledge from one content to another through a deliberate set of mental actions (Dewitz \& Graves, 2014), which are complex and part of a dynamic system of language acquisition (Nemati \& Taghizadeh, 2013). Participants were able to use whichever language that they were most comfortable in using throughout the Digital Storytelling Program. Most chose to code switch, moving between two languages, and using both languages allowed families to use their full linguistic repertoire to create stories.

We wanted the parents to know that they can and should use their native language and culture to support their children's literacy development, and that our role was to help them connect these skills and capacities with technology skills on their devices. However, when parents try to use Google to find a solution for a technical issue, they quickly found that the language barrier exists everywhere. One parent commented, "Almost everything, everything is in English. We want to learn about technology but we have to learn English first. I can be looking for something, and you put it in Spanish, and you will find various things in Spanish, but it won't find what you are looking for, things like that." As the parents and children started creating their stories, we scaffolded skill building when situations came up between language and technology. As the program continued, the parents become problem-solvers as they gained some technical vocabulary that allowed them to use search engines effectively.

\section{Confidence in Learning about Technology, Literacy and Storytelling}

As we started the Digital Storytelling programs, we assumed that since parents had access to smart phones and tablets they knew how to use them. So while they had access to devices they did not know how to use them for information gathering, and thus could not support their children in learning these skills as Braverman (2016) observed: "Children without a digitally 
savvy adult at home are more likely to use the Internet for entertainment purposes like watching a movie or communicating with friends via a social network that to do research or download an educational app.” (p. 20) At Morningside Elementary, we realized after the first session that we needed to step back and go over technology basics such as setting up a Gmail account, uploading a picture, etc. The technology skills demanded put parents in a difficult and vulnerable position in the beginning of the program: "Because once you are learning technology at the same time as the story, well they are the, it puts pressure on us...I will be very sincere. I didn't know anything. I didn't even know what, what what is this...what do you do with it. But now I say yes, commented of one the participant mother of the program. Using the design principles, we responded by creating a session about downloading apps, creating Gmail accounts, uploading files, and keeping information secure on the tablets and online sites. "Through the program, well, I learned how to open my email, and I didn't have it before," commented one of the parents. It was very important for us to make sure that the parents were comfortable with using the technology to create their stories and had access to the technology tools to help them in their lives outside of the program. We try to establish an environment where the parents took risks and asked questions in a supportive environment.

Initially, parents and their children were learning together the same skills at the same time; however, many of the parents were hesitant to work with their children because they were afraid that children would take over. After the first session at Morningside, we separated the children from the adults in learning group. Each group focused on the same skills, however, the parents were able to learn to navigate the technology depending on their knowledge skills about technology. When we started the program at Hamilton Elementary, we started with the parents in 
one room and the children learning in another from the lessons that we had learned from the earlier program.

Labbo, Eakle, and Montero (2002) believe that photography has "an important role to play in facilitating children's literacy experiences." (p. 6) Photo-taking and writing are both composing processes that help to develop visual and linguistic competencies. In the Digital Storytelling program, the parents and children made their own stories with their own photos so they could create meaningful, purposeful learning experiences. One parent reflected on the process of learning to use photos with smartphones or devices and then creating a sequence of pictures to tell the story: "How to put the photos [on the tablet]...I'd put them in order. We can put one or three and you can put text or whatever you want. The principle [thing]is how to experiment when using the tablet. That is what we did. Experimenting. We did experiments. But something good came out of it!"

At times, the photos became a catalyst for conversations, vocabulary building in both languages and confidence boosting. The digital stories gave the parents and the children an impetus for writing by sharing their knowledge with others. There was high personal interest in the stories because they were using their own photos allowing them to use what they knew in authentic ways. "What I learned is to be more interested. Because before I didn't like it [technology]. I wasn't interested. Now I am more interested" stated one of the parents. It became clear that the adults were staying away from technology with their children because they lacked the confidence that the engagement would be successful and the belief that it would be beneficial. Once they felt confident they were much more willing to engage. To help create their digital stories, we used the Little Story Creator. After downloading the app, the parents explored and got familiar with the app. One of the mothers commented, "Where to open the apps, where 
to close them... all of this. In order to make the story. How it begin it. And what you need to continue it as you go (laughing). We learned about the story. The beginning, the problem, the...the...solution, and the ending. And the surprise!"

Despite their familiarity with storytelling parents expressed gratitude about learning story elements, character development, using WH questions to help tell the story, developing a storyline, etc. while mastering the technology. They felt that it was a way to connect their actions during the program to school related activities.

\section{Coexistence [spending time together]}

The last theme coexistence name emerged from a parent comment: "the coexistence that you guys were patient with us [when using] the tablet." The parents were very enthusiastic about the sessions. They appreciated the opportunity to work with their children doing technology and literacy activities. "Jessica shared her story, and I shared my story with her," commented one parent that her and her daughter were to take turns and share their stories. The parents seemed to feel a renewed interest and excitement in their children's literacy development. In addition, their responses showed that parents had learned through the sessions which showed in the shift of their understanding of technology and storytelling as they gained new confidence in their abilities. "Now I see that it is okay to click/touch it. I learned how to click/touch the tablet and how to help the kids so that they learn how to make a story on the tablet. They do one part, and we do another but together. Yes," stated a parent participant. Digital storytelling allows children to develop their language, literacy, and storytelling abilities, along with their parents sitting sideby-side. This co-construction was a remarkable outcome for the Digital Storytelling Programs because the parents were able to experience the connection between technology and schoolbased literacy in storytelling. 


\section{APPLICATION OF THE PROGRAM}

In this chapter, we examined digital storytelling programs as a window into ways ELL Families can become storytellers with digital devices that enhance skills for success in school and beyond. It expands the broader field of research explores that adults' learning experiences with computers within family literacy programs (Edwards, 2006; Hughes \& Coyne, 1996) and families' technological literacies in the home (Dickinson \& Tabors, 2002; Lewis, 2009; 2013). Since there is little published research examining the impact of using digital resources with ELL Families, we believe that this design study is an important early step. Technology, now ubiquitous, can alter the language and literacy outcomes for young students, supporting biliteracy, and empowering parents to continue it in significant ways. Using the family as the unit of change made the program gains more sustainable because the change in family capacity for supporting of learning will not disappear even if the family moves or a program stops.

\section{Limitations and Next Steps}

This design study focused on families learning and interactions and did not directly measure technology knowledge, language knowledge, or school achievement in children or their parents. In subsequent studies we will focus on longitudinal measurement of language and literacy skills on both home language and English as well as growth in technology skills.

\section{CONCLUSION}

As with our previous family literacy program (Wessels, 2014), the digital storytelling programs were a proactive approach rather than reactive approach with the purpose to positively influence the literacy learning of children who are emerging bilinguals. Parents who needed to increase their technology, literacy and storytelling skills were motivated to participate in programs for the sake of their children more readily than in adult-only programs. It strengthened 
the bond between parents and children because it allowed for positive interaction and opened the door to discussion and opportunity. Developing a digital story provided opportunities for engaging interaction and opened the door to discussion on character development, vocabulary knowledge, expanded participants' imagination, and developed problem-solving skills. The digital stories bridged the oral, print, and digital media to become a permanent artifact that captured a specific moment in time, connecting home and school literacy expectations and practices that can be shared over time. By providing a meaningful experience for the families, the digital storytelling programs created a positive attitude toward life-long learning where technology has the most value when used jointly by children and adults. When families are involved, their children are more likely to be successful in school.

\section{REFERENCES}

Agar, M. (1996). The professional stranger: An informal introduction to ethnography. New York: Academic.

Albee, J. J., \& Drew, M. (2001). Off to the write start: A parent-teacher-child story. Reading Horizons: A Journal of Literacy and Language Arts, 41 (3). Retrieved from https://scholarworks.wmich.edu/reading_horizons/vol41/iss3/1

Baquedano-Lopez, P., Alexander, R. A., \& Hernandez, S. J. (2013). Equity issues in parental and community involvement in schools: What teacher educators need to know. Review of Research in Education, 37, 149 - 182.

Barrett, H. (2005). White Paper: Researching Electronic Portfolios and Learner Engagement. [Retrieved June 23, 2012 from http://www.taskstream.com/reflect/whitepaper.pdf] 
Berkowitz, T., Schaeffer, M. W., Maloney, E. A., Peterson, L., Gregor, C., Levine, S. C., \& Beilock, S. (2015). Math at home adds up to achievement at school. Science, 350, 196198.

Braverman, B. (2016). The digital divide: How income in- equality is affecting literacy instruction, and what all educators can do to help close the gap. Literacy Today, 33(4), 16-20.

Bus, A.G., van Ijzendorn, M.H., \& Pellegrini, A.D. (1995). Joint book reading makes for success in learning to read: A meta-analysis on intergenerational transmission of literacy, Review of Educational Research, 65, 1-21.

Cobb, P., Confrey, J., diSessa, A., Lehrer, R., Schauble, L. (2003). Design experiments in educational research. Educational Researcher, 32, 9-13.

Compton-Lilly, C., Rogers, R., \& Lewis, T. Y. (2012). Analyzing epistemological considerations related to diversity: An integrative critical literature review of family literacy scholarship. Reading Research Quarterly, 47(1), 33-60.

Conner, M. T. (2010). Beyond "acting white": The impact of culturally responsive pedagogy within a culture of accountability. Cambridge College.

Craig, S., Hull, K., Haggart, A., \& Crowder, E. (2001). Storytelling: Addressing the literacy needs of diverse learners. Teaching Exceptional Children, 43(5), 46-51.

Creswell, J.W. (2007). Qualitative inquiry and research design: Choosing among five approaches ( $2^{\text {nd }}$ edition). Thousand Oaks, CA: Sage Publications.

Cummins, J. (1986). Empowering minority students: A framework for intervention. Harvard Educational Review, 56(1), 18-36.

Deng, Q. \& Trainin, G. (2015). Learning vocabulary with apps: From theory to practice. The 
Nebraska Educator, 2, 49-69.

Dewitz, P. \& Graves, M., (2014). Teaching for transfer in the common core era. The Reading Teacher, 68(2), 149-158.

Dickinson, D. K., \& Tabors, P. O. (2002). Fostering language and literacy in classrooms and homes. Young Children, 57(2), 10-18.

Educause Learning Initiative (2007). 7 Things you should know about social content curation. Retrieved June 23, 2012 from: http://net.educause.edu/it/libraary/pdf/EL17089.pdf

Edwards, P. A. (2006). Family literacy and technology: Challenges and promising constructive designs. In M. McKenna, L. Labbo, R. Kieffer, \& D. Reinking (Eds.), Handbook of literacy and technology (2), pp 303-315. Mahwah, NJ: Lawrence Erlbaum Associates, Publishers.

Fiese, B. H. (2006). Family routines and rituals. New Haven, CT: Yale University Press.

Garcia, O. \& Kleifgen, J.A. (2010). Educating emergent bilinguals: Policies, programs and practices for English Language Learners. New York, NY: Teachers College Press.

Goldenberg, C. (2008). Teaching English language learners: What the research does—and does not—say. American Educator, 32(2), 8-44.

Goodrich, J. M., Lonigan, C. J., \& Farver, J. M. (2013). Do early literacy skills in children's first language promote development of skills in their second language? An experimental evaluation of transfer. Journal of Educational Psychology, 105(2), 414-426.

Hughes, B., \& Coyne, P. (1996). Meeting the Needs of 21st Century Literacy by Using Computers in Family Literacy Centers. (Paper presented at the National Reading Research Center Conference on Literacy and Technology for the 21st Century, October 4, 1996). Retrieved from https://archive.org/details/ERIC_ED411063 
Johnson, C. C., \& Fargo, J. D. (2014). A study of the impact of transformative professional development on hispanic student performance on state mandated assessments of science in elementary school. Journal of Science Teacher Education, 25(7), 845-859.

Kyle, D. W., McIntyre, E., Miller, K. B., \& Moore, G. H. (2005). Family connections: A basis for teacher reflection and instructional improvement. School Community Journal, 15(1),29-50. Retrieved from http://www.schoolcommunitynetwork.org/SCJ.aspx Labbo, D., A. Eakle, \& M.K. Montero. 2002. Digital language experience approach: using digital photographs and software as a language experience approach innovation. www.readingoline.org /electronic/labbo2/

Lambert, J. (2006). Seven Elements. Digital storytelling: Capturing lives, creating community, second edition (pp. 45 - 60). Berkeley, CA: Digital Diner Press.

Lee, J. S. (2002). The Korean language in America: The role of cultural identity in heritage language learning. Language, Culture and Curriculum, 15, 117-133.

Leu, D.J., Kinzer, C.K., Coiro, J., Castek, J., \& Henry, L.A. (2013). New literacies: A dual level theory of the changing nature of literacy, instruction, and assessment. In D.E. Alvermann, N.J. Unrau \& R.B. Ruddell (Eds.), Theoretical models and processes of reading (6th ed., pp. 1150-1181). Newark, DE: International Reading Association. Retrieved from www.reading.org/ Libraries/books/IRA-710-chapter42.pdf

Lewis, T. Y. (2009). Family literacy and digital literacies: A redefined approach to examining social Practices of an African-American family. Ph.D. State University of New York at Albany. Retrieved April 27, 2020 from https://www.learntechlib.org/p/127879/. 
Lewis, T. Y. (2013). "We Txt 2 Sty Cnnectd": An African American mother and son communicate: Digital literacies, meaning-making, and activity theory systems. Journal of Education, 193(2), 1-13.

Lonigan, C.J. \& Whitehurst, G.J. (1998). Relative efficacy of parent and teacher involvement in a shared-reading intervention for preschool children from low-income backgrounds. Early Childhood Research Quarterly, 17, 265-292.

López, D. (1996). Language: Diversity and assimilation. In R. Waldinger \& M. Bozormeyr (Eds.), Ethnic Los Angeles (pp.139-163). New York, NY: Russell Sage Foundation.

Malo, E., \& Bullard, J. (2000). Storytelling and the Emergent Reader. Paper presented at the International Reading Association World Congress on Reading (18th, Auckland, NewZealand, July 11-14, 2000). Retrieved from http://eric.ed.gov/?id=ED448464

Merriam, S. B. (2009). Qualitative research: A guide to design and implementation. San Francisco: Jossey-Bass.

Moje, E. B., K. M. Ciechanowski, K. Kramer, L. Ellis, R. Carrillo, and T. Collazo. 2004. "Working toward third space in content area literacy: An examination of everyday funds of knowledge and discourse." Reading Research Quarterly 39 (1): 38-70.

Moll, L. C., Amanti, C., Neff, D., \& González, N. (1992). Funds of knowledge for teaching: Using a qualitative approach to connect homes and classrooms. Theory into Practice, 31(2), 132-141.

Nemati, M., and Taghizadeh, M. (2013). Exploring similarities and differences between L1 and L2. International Research Journal of Applied and Basic Sciences, 4(9), 2477-2483.

Patton, M.Q. (2002). Qualitative research \& evaluation methods ( ${ }^{\text {rd }}$ edition). Thousand Oaks, CA: Sage Publications. 
Pew. (2013). Pew internet and family life project. Retrieved from http://www.pewinternet.org/

Proctor, C. P., August, D., Carlo, M. S., \& Snow, C. (2006). The intriguing role of Spanish language vocabulary knowledge in predicting English reading comprehension. Journal of Educational Psychology, 98(1), 159-169.

Rolla, A. (2002). Cross language interference in phonological awareness of Spanish-English bilingual children. Report retrieved from http://eric.ed.gov/?id=ED482581

Schecter, S. R., \& Bayley, R. 2002. Language as Cultural Practice: Mexicanos en el norte. Mahwah, NJ: Lawrence Erlbaum.

Scheele, A. F., Leseman, P. M., \& Mayo, A. Y. (2010). The home language environment of monolingual and bilingual children and their language proficiency. Applied Psycholinguistics, 31(1), 117-140.

Shavelson, R.J., Phillips, D.C., Towne, L., Feuer, M.J. (2003). On the science of education design studies. Educational Researcher, 32(1), 25-28.

Shin, F. H., \& Krashen, S. (1996). Teacher attitudes toward the principles of bilingual education and toward students' participation in bilingual programs: Same or different? Bilingual Research Journal, 20, 45-53.

Slavin, R., \& Cheung, A. (2003). A synthesis of research on beginning reading programs for English language learners. Institution of Education Sciences, U.S. Department of Education.

Strucker, J. Snow, C., \& Alexander Pan, B. (2004). Family literacy for ESOL families: challenges and design principles. In Wasik, B., ed. (2004). Handbook of family literacy. Mahwah, NJ: Lawrence Erlbaum Associates. 
Tesch, R. (1990). Qualitative research: Analysis types and software tools. New York: RoutledgeFalmer.

Trainin, G, Wessels, S., Nelson, R., Vadasy, P. (2017). Emergent literacy experiences of young Latino English learners. Early Childhood Education Journal, 24 (5).

Wessels, S. (2014). Supporting English and Spanish literacy through a family literacy program. The School Community Journal, 24 (2), 147-163.

\section{ADDITIONAL READINGS:}

Anderson, J., Smythe, S., \& Shapiro, J. (2005). Working and learning with families, communities, and schools: a critical case study. In Anderson, J., Kendrick, M, Rogers, T., Smythe, S., eds. (2005). Portraits of literacies across families, communities and schools: intersections and tensions. Mahwah, New Jersey: Lawrence Erlbaum Associates.

Auerbach, E. (1995). Deconstructing the discourse of strengths in family literacy. Journal of Reading Behavior, 27, 643-661.

Burns, S., Griffin, P., \& Snow, C.E. (eds.) (1999). Starting out right: A guide for promoting children's reading success. Washington DC: National Reading Academy.

Daftarifard, P., \& Shirkhani, S. (2011). Transfer across second language acquisition theories. Journal on English Language Teaching, 1(3), 1-6.

Delgado-Gaitan, C. (1990). Literacy for empowerment: the role of parents in children's education. London: Falmer Press.

Fuligni, A. \& Brooks-Gunn, J. (2004). Early childhood intervention in family literacy programs. In Wasik, B., ed. (2004). Handbook of Family Literacy. Mahwah, NJ: Lawrence Erlbaum Associates. 
Galindo, R., \& Medina, C. (2009). Cultural appropriation, performance, and agency in Mexicana parent involvement. Journal of Latinos in Education, 8, 312-331.

Griffin, E.A. \& F.J. Morrison (1997). The unique contribution of home literacy environment to differences in early literacy skills. Early Childhood Development and Care, 127-128: 233-243.

Harbin, G., Herrmann, S., Wasik, B., Dobbins, D., Lam, W. (2004). Integrating services for family learning. In Wasik, B., ed. (2004). Handbook of Family Literacy. Mahwah, NJ: Lawrence Erlbaum Associates.

Heath, S. (1983). Ways with words: language, life and work in communities and classrooms. Cambridge, UK: Cambridge University Press.

Johnson, L. (2009). Challenging "best practices" in family literacy and parent education programs: the development and enactment of mothering knowledge among Puerto Rican and Latina mothers in Chicago. Anthropology \& Education Quarterly, 40(3) 257-276.

Lewis, T. Y. (2013). "We Txt 2 Sty Cnnectd": An African American mother and son communicate: Digital literacies, meaning-making, and activity theory systems. Journal of Education, 193(2), 1-13.

Mandel Morrow, Mandelson, A. \& Kuhn, M. 2010). Characteristics of three family literacy programs that worked. In Dunsmore, K. \& Fisher, D. eds. (2010). Bringing Literacy Home. Newark, DE: International Reading Association.

Millikin-Lynch, P. (2009). Family matters: how one Somali Bantu family supported themselves and an American teacher in literacy learning. In Li, G., ed. (2009). Multicultural families, home literacies and mainstream schooling. Charlotte, NC: Information Age Publishing Inc. 
Phillips, L. \& Sample, H. (2005). Family literacy: listen to what families have to say. In Anderson, J., Kendrick, M, Rogers, T., Smythe, S., eds. (2005). Portraits of literacies across families, communities and schools: intersections and tensions. Mahwah, NJ: Lawrence Erlbaum Associates

Seger, J. (2011). The new digital [st]age: Barriers to the adoption and adaptation of new technologies to deliver extension programming and how to address them. Journal of Extension, 49(1), Article 1FEA1.

Taylor, D. (1983). Family literacy: young children learning to read and write. Exeter, NH: Heinemann Educational Books.

\section{KEY TERMS AND DEFINITIONS}

Code-Switching: Code-switching is alternating or mixing the use of two or more languages in the same discourse.

Digital Literacy: Digital Literacy is the ability to use, create and read information using technology.

English Language Learner (ELL): Students for who English in not their first language but are in the process of acquiring the English language.

Funds of Knowledge: Funds of knowledge are untapped cultural experiences of English Language Learners.

\section{Appendix 1: Family Technology Survey}

Name

How many kids do you have? 
What language(s) do you use in your home?

What technology do you have at home?

Computer

Tablet

iPad

Cellphone with internet access

Other

Home Technology Environment

Circle the answers below that best match the technology use in your home:

How many hours per day do you use computers, tablets, or iPads?

$\begin{array}{llllll}0-1 & 2-3 & 4-5 & 6-7 & 8-9 & 10 \text { or more }\end{array}$

How many hours per day do your kids use computers, tablets, or iPads?

$\begin{array}{llllll}0-1 & 2-3 & 4-5 & 6-7 & 8-9 & 10 \text { or more }\end{array}$

Where do you use technology?

Work Home Library Other

Where do your kids use technology?

School Home Library Other

Do you use technology with your kids?

Yes No

Do you help your kids with technology?

Yes No

Do your kids help you with technology?

Yes No

Why do you use technology?

Homework/School

Work

Games Facebook Music Movies

Skyping with Family Other

Why do you your kids use technology?

Homework/School Games

Skyping with Family Other

Facebook Music Movies

Definition

Technology is

Accessibility

Circle the answers that best match what you have access to at home or work. 


\begin{tabular}{|l|l|l|l|l|}
\hline Computer & $\begin{array}{l}\text { I don't have and } \\
\text { don't use. }\end{array}$ & $\begin{array}{l}\text { I have but don't } \\
\text { use. }\end{array}$ & $\begin{array}{l}\text { I have but need } \\
\text { help using. }\end{array}$ & I have and I use. \\
\hline Tablet or iPad & $\begin{array}{l}\text { I don't have and } \\
\text { don't use. }\end{array}$ & $\begin{array}{l}\text { I have but don't } \\
\text { use. }\end{array}$ & $\begin{array}{l}\text { I have but need } \\
\text { help using. }\end{array}$ & I have and I use. \\
\hline Cellphone & $\begin{array}{l}\text { I don't have and } \\
\text { don't use. }\end{array}$ & $\begin{array}{l}\text { I have but don't } \\
\text { use. }\end{array}$ & $\begin{array}{l}\text { I have but need } \\
\text { help using. }\end{array}$ & I have and I use. \\
\hline Internet & $\begin{array}{l}\text { I don't have and } \\
\text { don't use. }\end{array}$ & $\begin{array}{l}\text { I have but don't } \\
\text { use. }\end{array}$ & $\begin{array}{l}\text { I have but need } \\
\text { help using. }\end{array}$ & I have and I use. \\
\hline
\end{tabular}

Enjoyment

Circle the answers that best match your feelings.

\begin{tabular}{|l|l|l|l|l|l|l|}
\hline $\begin{array}{l}\text { Using the } \\
\text { computer }\end{array}$ & I hate it. & $\begin{array}{l}\text { I don't really } \\
\text { like it, but I } \\
\text { don't hate it. }\end{array}$ & $\begin{array}{l}\text { I have no } \\
\text { feelings } \\
\text { about it. }\end{array}$ & $\begin{array}{l}\text { I like it, but } \\
\text { don't love it. }\end{array}$ & I love it. & $\begin{array}{l}\text { I don't have or } \\
\text { don't use. }\end{array}$ \\
\hline $\begin{array}{l}\text { Using a tablet } \\
\text { or iPad }\end{array}$ & I hate it. & $\begin{array}{l}\text { I don't really } \\
\text { like it, but I } \\
\text { don't hate it. }\end{array}$ & $\begin{array}{l}\text { I have no } \\
\text { feelings } \\
\text { about it. }\end{array}$ & $\begin{array}{l}\text { I like it, but } \\
\text { don't love it. }\end{array}$ & I love it. & $\begin{array}{l}\text { I don't have or } \\
\text { don't use. }\end{array}$ \\
\hline $\begin{array}{l}\text { Using the } \\
\text { internet }\end{array}$ & I hate it. & $\begin{array}{l}\text { I don't really } \\
\text { like it, but I } \\
\text { don't hate it. }\end{array}$ & $\begin{array}{l}\text { I have no } \\
\text { feelings } \\
\text { about it. }\end{array}$ & $\begin{array}{l}\text { I like it, but } \\
\text { don't love it. }\end{array}$ & I love it. & $\begin{array}{l}\text { I don't have or } \\
\text { don't use. }\end{array}$ \\
\hline $\begin{array}{l}\text { Using } \\
\text { technology } \\
\text { with my kids }\end{array}$ & I hate it. & $\begin{array}{l}\text { I don't really } \\
\text { like it, but I } \\
\text { don't hate it. }\end{array}$ & $\begin{array}{l}\text { I have no } \\
\text { feelings } \\
\text { about it. }\end{array}$ & $\begin{array}{l}\text { I like it, but } \\
\text { don't love it. }\end{array}$ & I love it. & $\begin{array}{l}\text { I don't have or } \\
\text { don't use. }\end{array}$ \\
\hline $\begin{array}{l}\text { Learning } \\
\text { about } \\
\text { technology }\end{array}$ & I hate it. & $\begin{array}{l}\text { I don't really } \\
\text { like it, but I } \\
\text { don't hate it. }\end{array}$ & $\begin{array}{l}\text { I have no } \\
\text { feelings } \\
\text { about it. }\end{array}$ & $\begin{array}{l}\text { I like it, but } \\
\text { don't love it. }\end{array}$ & I love it. & $\begin{array}{l}\text { I don't have or } \\
\text { don't use. }\end{array}$ \\
\hline
\end{tabular}

Value

Circle the answers that best match what you think or believe.

\begin{tabular}{|l|l|l|l|l|l|l|}
\hline $\begin{array}{l}\text { Using the } \\
\text { internet to find } \\
\text { answers to } \\
\text { questions }\end{array}$ & $\begin{array}{l}\text { I can't and } \\
\text { don't want } \\
\text { to. }\end{array}$ & $\begin{array}{l}\text { I can't but } \\
\text { want to. }\end{array}$ & $\begin{array}{l}\text { I have } \\
\text { never } \\
\text { tried. }\end{array}$ & $\begin{array}{l}\text { I can but } \\
\text { don't. }\end{array}$ & I can and do. & $\begin{array}{l}\text { I don't have or } \\
\text { don't use. }\end{array}$ \\
\hline $\begin{array}{l}\text { Using the } \\
\text { internet to learn } \\
\text { new things }\end{array}$ & $\begin{array}{l}\text { I can't and } \\
\text { don't want } \\
\text { to. }\end{array}$ & $\begin{array}{l}\text { I can't but } \\
\text { want to. }\end{array}$ & $\begin{array}{l}\text { I have } \\
\text { never } \\
\text { tried. }\end{array}$ & $\begin{array}{l}\text { I can but } \\
\text { don't. }\end{array}$ & I can and do. & $\begin{array}{l}\text { I don't have or } \\
\text { don't use. }\end{array}$ \\
\hline Using the & I can't and & I can't but & I have & I can but & I can and do. & I don't have or \\
\hline
\end{tabular}




\begin{tabular}{|l|l|l|l|l|l|l|}
\hline $\begin{array}{l}\text { internet to help } \\
\text { my kids with } \\
\text { school }\end{array}$ & $\begin{array}{l}\text { don't want } \\
\text { to. }\end{array}$ & want to. & $\begin{array}{l}\text { never } \\
\text { tried. }\end{array}$ & don't. & don't use. \\
\hline
\end{tabular}

Perceived Competence

Circle the answers that best match your comfort with technology.

\begin{tabular}{|l|l|l|l|l|l|l|}
\hline $\begin{array}{l}\text { Using } \\
\text { technology for } \\
\text { fun }\end{array}$ & $\begin{array}{l}\text { I can't and } \\
\text { don't want } \\
\text { to. }\end{array}$ & $\begin{array}{l}\text { I can't } \\
\text { but want } \\
\text { to. }\end{array}$ & $\begin{array}{l}\text { I have } \\
\text { never } \\
\text { tried. }\end{array}$ & $\begin{array}{l}\text { I can but } \\
\text { don't. }\end{array}$ & I can and do. & $\begin{array}{l}\text { I don't have or } \\
\text { don't use. }\end{array}$ \\
\hline $\begin{array}{l}\text { Using } \\
\text { technology for } \\
\text { work }\end{array}$ & $\begin{array}{l}\text { I can't and } \\
\text { don't want } \\
\text { to. }\end{array}$ & $\begin{array}{l}\text { I can't } \\
\text { but want } \\
\text { to. }\end{array}$ & $\begin{array}{l}\text { I have } \\
\text { never } \\
\text { tried. }\end{array}$ & $\begin{array}{l}\text { I can but } \\
\text { don't. }\end{array}$ & I can and do. & $\begin{array}{l}\text { I don't have or } \\
\text { don't use. }\end{array}$ \\
\hline $\begin{array}{l}\text { Helping my } \\
\text { kids with } \\
\text { technology }\end{array}$ & $\begin{array}{l}\text { I can't and } \\
\text { don't want } \\
\text { to. }\end{array}$ & $\begin{array}{l}\text { I can't } \\
\text { but want } \\
\text { to. }\end{array}$ & $\begin{array}{l}\text { I have } \\
\text { never } \\
\text { tried. }\end{array}$ & $\begin{array}{l}\text { I can but } \\
\text { don't. }\end{array}$ & I can and do. & $\begin{array}{l}\text { I don't have or } \\
\text { don't use. }\end{array}$ \\
\hline
\end{tabular}

Adapted from:

Baker, L. (2002). Beginning readers' motivation for reading in relation to parental beliefs and home readings experiences. Reading psychology, 23, 239-269.

Griffin, E., \& Morrison, F. (1996). The unique contribution of home literacy environment to difference in early literacy skills. Early childhood development and care, 127(1), 233-243. 